\title{
Education for Sustainable Development and the Implementation of "Tokkatsu" in Indonesia
}

\author{
Kanako N. Kusanagi \\ Center for Advanced School Education and Evidence-based Research (CASEER), \\ Graduate School of Education, University of Tokyo \\ kusanagiknk@gmail.com
}

\begin{abstract}
In this era of disruption, we are constantly facing the challenges of a changing world. The role of education is no longer limited to the transfer of knowledge and skills. As represented by Sustainable Development Goal 4, Education for Sustainable Development, the role of education is expanding in order to prepare young citizens who can not only cope with rapidly changing social conditions but who also have the capacity to transform society into a more sustainable one. Not surprisingly, equipping these next-generation citizens with intangible skills such as discipline, ethics, and morality has become a priority for educators internationally. It is in this context that there has been emerging interest in "tokkatsu," a holistic Japanese approach to educating children. In this paper, tokkatsu is presented as a promising approach to addressing some of the serious issues in the Indonesian educational system, with a focus on developing the social skills, ethical framework and values of Indonesia's next generation.
\end{abstract}

Keywords: sustainable development, tokkatsu

\section{INTRODUCTION}

\section{A. Industry 4.0 and a human-centered approach}

In 2018, President Joko Widodo launched "Making Indonesia 4.0" [1], a roadmap to the future in which innovation is seen as crucial. This has resulted in an increased emphasis on Science, Technology, Engineering and Mathematics (STEM) education. However, innovation should not be limited to digital technology and science. In this regard, I was pleased to see the role of social studies in innovation featured on the ICOSSEI website in the form of "Learning Innovation in Social Studies: Social studies helps students gain the knowledge, skills, and attitudes they need to become informed global citizens." Innovation in the next generation requires abilities beyond those needed in technology and hard science. In recognition of this reality, the Japanese government is promoting Society 5.0, defined as

1) human-centered society that balances economic advancement with the resolution of social problems by a system that highly integrates cyberspace and physical space (Cabinet Office, n.d.).

Such a human-centered approach is needed since the ability to identify and solve problems is the key to social innovation. Unlike digital technology, social innovation is context-dependent and requires focused knowledge of local societies and the people who comprise those societies. Smartphones can be used anywhere in the world, but solutions to social issues are often unique to particular cultures, geographic areas or groups of people. For example, the poverty issues faced by the people of Eastern Indonesia are very different from the poverty issues faced by the poor of New York City.

In raising the next generation of citizens, there are expanding demands for education to meet the complex needs of tomorrow's society. In the concept of Education for Sustainable Development (ESD), this is described as "foster(ing) individuals who will contribute to the realization of a socially, economically, and environmentally more sustainable society" [2]. One of the more significant challenges arises from the fact that this balance of social, environmental, and economic development varies across societies. In order to raise citizens who can contribute to the creation of a sustainable society, a holistic approach - one that is interdisciplinary, learner-centered, and contextdependent, and has the ability to empower learners for the necessary societal transformation-is needed [3]. Raising responsible citizens who can take effective action in promoting sustainable development will be critical. Thus, the role of education needs to be expanded to include nurturing in society's children and young adults habits of ethical behavior, integrity, morals, and values in order for them to take responsible action in creating and sustaining a better society.

Traditionally, the development of noncognitive skills has not been considered a central responsibility of primary and secondary schools in most countries, including Indonesia. According to [4], such noncognitive skills would include "interpersonal skills, motivation, emotional maturity, the ability to concentrate, the ability to care, self-control, (a 
however, there are no specific guidelines regarding how this should be implemented at the school level, and many schools admit that there has been little effort to incorporate character education in their subject teaching

\section{DISCUSSION} multi-level, spirited discussions of how best to foster the noncognitive aspects of development through education.

There have, of course, been attempts to teach students "correct" values and morality through moral or citizenship education. In the Indonesian context, the government has been promoting its "Mental Revolution," conducting a series of campaigns to encourage a constructive change in the mindset of its citizens. In essence, this represents an effort to ensure clean, corruption-free, and efficient bureaucratic government services. However, social skills are not something that can be easily "taught." Moreover, changing the mindset of others is unlikely to happen overnight. Thus, a fundamental challenge is how to replace the largely top-down, psychological approach characteristic of most traditional educational systems with a more holistic, systematic, gradual, and bottomup approach.

\section{B. Character education in Indonesia}

In Indonesia, recent curriculum changes reflect movement towards a more holistic and interdisciplinary approach. Curriculum 2013 is integrative and more thematic. Moreover, there has been a growing recognition that the need for character education is urgent; in fact, it has been stipulated that the principles of character education need to be taught across subjects [6]. In 2017, President Joko Widodo [7] signed a presidential decree strengthening character education in Indonesian schools [7]. According to the government website [8], the purposes of character education are:

- Building and equipping students, as the golden generation of Indonesia in 2045, to face the dynamics of change in the future;

- Developing a national education platform that places character education as the main soul by taking into account the diversity of Indonesian culture;

- Revitalizing and strengthening the potential and competence of the education ecosystem.

Character education in Indonesia focuses on five core values: religiosity, nationalism, independence, mutual cooperation, and integrity [9]. It calls for cooperation between school, family, and community, with the conviction that this will encourage optimum character development for the children. Some of the positive goals of the PKK Program for elementary school students include flexible thinking, developing good relationships, and being able to show an emotional, social, and empathetic side. Unfortunately,

\section{A. Transforming Teaching and Learning in Indonesian Classrooms}

As described in section 1, we are seeing a global trend towards a more holistic approach in education in order to meet expanding demands to nurture both the cognitive and noncognitive development of children. However, there are many challenges to implementing a "holistic approach that is interdisciplinary, learner-centered, context-dependent, and empowers learners for societal transformation" [3]. Based on my experience working with Indonesian schools in support of teacher development, several key issues in pedagogical transformation toward ESD have become apparent [10-11].

Firstly, educational quality is currently being assessed based on the academic performance of students due to the strong exam-culture. When the goal of education is simply access (enrollment rate), the result is relatively easy to measure. However, judging educational quality is far more difficult, as educational quality is affected by many factors. However tempting, the results of standardized tests alone cannot be used to direct efforts to improve learning. Given the regional disparities in resources, the ranking of schools as commonly practiced in Indonesia discourages those who are left behind. More emphasis needs to be placed on improving the process of student learning and collaboration among students.

Secondly, in the current competitive environment, collaborative learning is difficult to establish. When students are competing with one another, responsibility for learning is individualized. Moreover, even when group work and handson activities are introduced, students lack the skills necessary for active learning. They tend not to interact with the group and prefer to solve a problem or write down their answers individually. They are understandably reluctant to help their peers since they see their peers as competitors.

Thirdly, teachers are used to didactic methods of teaching directed at exam-preparation and do not generally believe that their responsibility extends to facilitating student learning. They commonly believe that the responsibility for learning rests solely with the students and that the ability of students to engage in problem-solving independently rather than with the support of their teachers should be highly valued. Given this conviction, it is not surprising that the aim of student activities is strictly to produce the correct answer and that worksheets primarily consist of fill-in-the-blank questions. 
Fourthly, social learning is commonly treated as a fun and unique experience separate from academic learning. For example, in a fieldwork program for school children organized by a local NGO and sponsored by an international company, students visited a pearl farm to learn firsthand about the pearl culture process that they had been studying. However, the students found it difficult to connect what they observed in the field to what they had learned in the classroom. In the end, students merely filled in their worksheets by copying word-for-word the words of the factory guide. Especially in preparing young people for vocational training, the ability to integrate knowledge and skills gained in school into real-life situations is essential.

Based on the issues described in section 2.1, the challenges in ESD — especially character education — in Indonesia can be listed as follows:

Firstly, there needs to be a more consistent and bottom-up approach in education. While character education is emphasized in the 2013 curriculum, there has been no longterm, consistent vision or defined mission in Indonesian schools due to the lingering effects of the past top-down education system. When the head of the Education Office or the school principal changes, often a new policy is implemented. This makes it difficult to offer consistent and coherent educational programs. A more grass-roots, schoolbased approach relevant to local issues is needed. Although, at the policy level, there have been efforts made in this regard, as represented by School-based Curriculum 2006, in reality, such curricular changes have had very little impact. Especially in character education, cooperation between school, family, and community is essential. To accomplish this, a long-term vision is needed to develop and promote programs that produce gradual and consistent change.

Secondly, the definition of learning should expand beyond academic or cognitive aspects. Because of the strong emphasis on the academic goals of education, teachers in Indonesia are seen as little more than deliverers of the curriculum. When the quality of education is measured solely by a paper examination, noncognitive aspects will inevitably be neglected. Even where character education has been introduced in Indonesian schools, it has generally been treated separately from academic learning despite the fact that, to be fully effective, the cognitive and noncognitive aspects of learning should be integrated. The role of teachers should no longer be solely that of instructor and evaluator; rather, teachers should be learning facilitators who can work closely with their students, support the process of student learning, and help develop both cognitive and noncognitive skills.

Thirdly, a democratic classroom/school environment is needed in order to establish collaboration and dialogue in schools. School leadership is not distributed among teachers, and students have almost no opportunity to engage in decision-making in the classroom. However, in order to nurture responsible citizens who are willing to take action for a better society, such participatory experiences in school/classroom management are important.

\section{B. The Possibility of Tokkatsu in Indonesia}

According to the Ministry of Education, Culture, Sports, Science and Technology (MEXT), tokkatsu "provides educational activities in which the school and classrooms are considered as "societies"" where "independent and practical attitudes are cultivated in children to enable them to build a better group life and make better personal selves" [12]. The uniqueness of tokkatsu is that various non-academic activities are provided as part of the educational experience and included within the curriculum along with academic subjects.

Perhaps the most widely-known tokkatsu activities are school cleaning and serving the school lunch. However, these are only part of the overall framework of tokkatsu. As shown in Figure 1, tokkatsu includes classroom activities, student council, club activities, and school events. Activities such as the entrance ceremony, graduation ceremony, club activities, student council activities, evacuation drills, community service, and various cultural festivals are just a few examples. These activities may not be unique to the Japanese curriculum; however, the way in which these activities are integrated for a common purpose under the tokkatsu curriculum is unique. By joining in a variety of student activities and being a member of different types of communities, the students learn to collaborate within various group settings. The experience of managing different kinds of self-initiated activities provides students first-hand opportunities to take part in collaborative decision-making, organizing, and carrying out responsibilities. Most of all, the students generally enjoy these kinds of activities and the company of one another.

Tokkatsu was introduced in Indonesia in 2018, and cases involving its implementation are limited. For the most part, the teachers/lecturers who are interested in tokkatsu have had the experience of implementing another Japanese educational model-lesson study — which is a systematic program for the collaborative professional development of teachers. Indonesian teachers have generally encountered challenges in lesson study because Indonesian students have had little experience in an interactive approach, which hinders their active engagement in collaborative learning. Thus, teachers who are interested in tokkatsu are keen to build a classroom culture that improves the quality of student learning. Two examples are provided below. 
TOKUBETSU KATSUDO-OVERALL PLAN

\begin{tabular}{|c|c|c|c|c|c|c|}
\hline & $\begin{array}{l}\text { Ideal Pupils } \\
\text { Study on their own } \\
\text { Think for themselves } \\
\text { Have high, clear aims }\end{array}$ & \multicolumn{3}{|c|}{$\begin{array}{c}\text { Aims of School Education } \\
\text { Children who think before acting } \\
\text { Motivated children } \\
\text { Happy, energetic children }\end{array}$} & \multicolumn{2}{|r|}{$\begin{array}{c}\text { Japanese Constitution } \\
\text { School Education Act } \\
\text { Fundamental Education Act } \\
\text { Educational Guidelines } \\
\text { Tokyo and Machida City Educational Aims }\end{array}$} \\
\hline \multicolumn{2}{|c|}{$\begin{array}{l}\text { Classes } \\
\text { Develop a willingness in the pupils to find } \\
\text { problems to study and try to solve them on their } \\
\text { own. }\end{array}$} & \multicolumn{3}{|c|}{$\begin{array}{l}\text { Tokubetsu Katsudo's Aims } \\
\text { - Through effective group activities, aim for well-rounded } \\
\text { development and more individuality. At the same time, } \\
\text { develop an awareness of belonging to the group; build an } \\
\text { active, positive attitude toward cooperating to make daily life } \\
\text { better. }\end{array}$} & \multicolumn{2}{|c|}{$\begin{array}{l}\text { The Situation in the Community } \\
\text { - The interest in education is high; people are very } \\
\text { cooperative. Sport events, etc planned and carried } \\
\text { out by the parents and other residents are popular. }\end{array}$} \\
\hline \multicolumn{2}{|c|}{$\begin{array}{l}\text { Morals } \\
\text { Build sound judgment, act independently to try to } \\
\text { make life better. } \\
\text { Develop an attitude to try to build strong personal } \\
\text { relations in groups and society. }\end{array}$} & \multirow{3}{*}{\multicolumn{3}{|c|}{\begin{tabular}{|l|}
\multicolumn{1}{|c|}{ This School's Tokkatsu Aims: } \\
\\
- Through classroom activities, develop a personal concern in \\
each pupil about various problems. Encourage a positive \\
attitude in trying to make school life better. \\
- Through Student Council activities, heighten an awareness \\
of group membership. Build an attitude of freely joining in \\
and following through to the end. \\
- Through club activities, develop a stronger, more positive \\
personality and more independence. \\
- Through various school activities, experience a fulfilling \\
school life and high aims. \\
- Through combined- class activities, aim at enthusiasm to \\
associate with other grades.
\end{tabular}}} & \multirow{2}{*}{\multicolumn{2}{|c|}{$\begin{array}{l}\text { Communication with the Community } \\
\text { - The school keeps in close touch with the parents } \\
\text { and community - making the policy of running the } \\
\text { school, grades, and classes clear, trying to gain the } \\
\text { residents' understanding and cooperation. We try } \\
\text { to get as many opinions as possible from the } \\
\text { community and make use of them. We also have } \\
\text { parents and residents act as volunteer instructors. }\end{array}$}} \\
\hline \multicolumn{2}{|c|}{$\begin{array}{l}\text { Integrated Studies } \\
\text { Have the pupils find their own themes. Develop } \\
\text { the ability to live to the fullest by thinking, making } \\
\text { decisions, solving problems on their own. } \\
\text { Through many experiences, foster an active, } \\
\text { creative attitude toward his/her way of life and } \\
\text { developing a well-rounded whole child. }\end{array}$} & & & & & \\
\hline \multicolumn{2}{|c|}{$\begin{array}{l}\text { Foreign Languages } \\
\text { Develop the ability to communicate with people of } \\
\text { other cultures }\end{array}$} & & & & & \\
\hline \multicolumn{7}{|c|}{ Abilities to be Developed through Tokkatsu } \\
\hline \multicolumn{3}{|c|}{ Lower grades } & \multicolumn{2}{|c|}{ Middle grades } & & Upper grades \\
\hline \multicolumn{3}{|c|}{$\begin{array}{l}\text { Develop the children's ability to have friendly interaction } \\
\text { with classmates and make school life more enjoyable. }\end{array}$} & \multicolumn{2}{|c|}{$\begin{array}{l}\text { Develop the children's ability to cooperate with each other to } \\
\text { make classroom life more enjoyable. }\end{array}$} & \multicolumn{2}{|c|}{$\begin{array}{l}\text { Develop the ability to take part in many activities to } \\
\text { make school life better. }\end{array}$} \\
\hline \multicolumn{2}{|r|}{ Classroom Activities } & \multicolumn{3}{|r|}{ Club Activitic } & \multicolumn{2}{|r|}{ School Events } \\
\hline 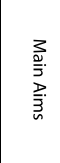 & $\begin{array}{l}\text { - Develop an active, positive attitude } \\
\text { toward school life. } \\
\text { - Encourage serious, personal concern } \\
\text { about various problems. }\end{array}$ & \multicolumn{2}{|c|}{$\begin{array}{l}\text { - Talk things over freely, openly. Develop } \\
\text { an active, positive attitude toward } \\
\text { making school life and activities full and } \\
\text { enjoyable. }\end{array}$} & \multicolumn{2}{|c|}{$\begin{array}{l}\text { - Develop the ability for children with } \\
\text { the same interests to act freely and } \\
\text { spontaneously. Develop the ability to } \\
\text { find their own interests and cooperate } \\
\text { with other club members. }\end{array}$} & $\begin{array}{l}\text { - Aim at bringing change and order to } \\
\text { school life, strengthening a feeling of } \\
\text { belonging to the group, developing a } \\
\text { healthy body and mind. Also letting } \\
\text { them experience first hand, a full, } \\
\text { meaningful school life. }\end{array}$ \\
\hline 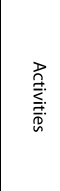 & $\begin{array}{l}\text { - Discussion activities } \\
\text { - Classroom committees } \\
\text { - Morning meetings / End-of-the-day } \\
\text { meetings } \\
\text { - Long group activities } \\
\text { School festival } \\
\text { Farewell party for } 6 \text { th graders }\end{array}$ & \multicolumn{2}{|c|}{$\begin{array}{l}\text { - Class representatives'meeting } \\
\text { - Committees: planning, art, sports, } \\
\text { beautification, animal care, school lunch, } \\
\text { announcements, health, music, science } \\
\text { - Long activities: school festival, farewell } \\
\text { party for 6th graders }\end{array}$} & \multicolumn{2}{|c|}{$\begin{array}{l}\text { badminton, 'pot' basketball, dodge, kick } \\
\text { base, track and field, table tennis, soft } \\
\text { volleyball, soccer, illustration, cooking, } \\
\text { scientific experiments, computer, } \\
\text { Japanese drums } \\
\text { - Each club meets } 15-20 \text { times during } \\
\text { the school year. }\end{array}$} & $\begin{array}{l}\text { - Formal events } \\
\text { - Academic events } \\
\text { - Health, safety related events } \\
\text { - Field trips overnight trips }\end{array}$ \\
\hline 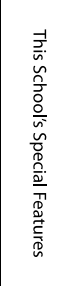 & $\begin{array}{l}\text { - Encourage independence by having } \\
\text { the children actively take part in } \\
\text { planning and coordinating events. } \\
\text { - Teach the children to become good } \\
\text { listeners and speakers -listen carefully } \\
\text { to their classmates and express their } \\
\text { own opinions clearly. } \\
\text { - Give the children a chance to take part } \\
\text { in creative, enjoyable classroom } \\
\text { committees. }\end{array}$ & \multicolumn{2}{|c|}{$\begin{array}{l}\text {-Have the children in other grades play } \\
\text { with the } 1 \text { st graders. } \\
\text { - Have combined -grade groups go } \\
\text { around to different booths at the festival } \\
\text { - To promote an orderly school life, have } \\
\text { the Student Council take up rules like: } \\
\text { "Quiet in the halls. Keep to the right."The } \\
\text { children will learn the importance of } \\
\text { following rules. } \\
\text { - Think about impoverished children in } \\
\text { the world. Cooperate with UNICEF. }\end{array}$} & \multicolumn{2}{|c|}{$\begin{array}{l}\text { - If the children show an interest in } \\
\text { setting up a new club, the teacher } \\
\text { should help make this possible. } \\
\text { - With the 6th graders as leaders, } \\
\text { emphasize interaction between grades. } \\
\text { Strengthen the children's independence. } \\
\text { - Try to utilize open space in the } \\
\text { community. } \\
\text { - In the Japanese Drum Club etc. invite } \\
\text { volunteers to come and help improve } \\
\text { the children's skills. }\end{array}$} & $\begin{array}{l}\text { - Have a joint } 1 \text { st and } 2 \text { nd grade outing } \\
\text { - Have the children take part in } \\
\text { planning and coordinating school } \\
\text { events } \\
\text { ( Sports Day, academic presentations, } \\
\text { etc.) } \\
\text { - Have the children tell about their aims } \\
\text { and achievements at the Opening } \\
\text { Ceremony and the Closing Ceremony }\end{array}$ \\
\hline
\end{tabular}

Fig. 1. Overall Plan of Tokkatsu [5] 


\section{Kindergarten and Elementary School of School Y}

School $\mathrm{Y}$ is a private school managed by a Catholic foundation. Private religious schools are commonly believed to provide good character education. For this reason, the parents of Scool Y tend to send their children to the school largely because of the character education it offers. The school came to know about tokkatsu through Mr. Tatang Suratno, a lecturer at the Indonesia University of Education. The uniqueness of the tokkatsu activities at Scool $\mathrm{Y}$ is that the values promoted by these activities are similar to those associated with the Catholic religious values promoted by the school-sensitivity, reasoning, creativity, development, and conscience. Although tokkatsu itself is secular, it teaches ethics and morality as the foundation for responsible community membership. For example, in one of the observed activities, students learned how to share a book among four members of the community. They learned to say "I am sorry" and how to ask for permission to borrow a book. At first, the students had difficulty taking turns and were not listening to others in the group. However, with teacher facilitation, they produced solutions regarding how to treat one another politely and found solutions that everyone could agree upon. Here and elsewhere, tokkatsu is being used as a framework to strengthen and integrate various programs related to character education.

\section{Social Science Department at the University of Malang}

Mr. I Dewa Putu Eskasasnanda, a lecturer in the Social Science Department at the University of Malang, has introduced tokkatsu activities into his cultural anthropology classroom. According to Mr. Eskasasnanda [13], his purpose was to enhance the social skills of his students. He had found that, having had little experience in collaboration before entering the university, his students generally lacked the ability to work collaboratively. They often worked on group assignments through online communications and rarely had face-to-face interactions. The students also lacked the motivation to learn, as listening to long lectures delivered to a large class provides little stimulation. Given the prevalence of such a condition, finding ways for students to acquire necessary soft skills before entering the workforce has become a major issue at the university level.

The introduction of games (such as that shown in the photo) enabled Mr. Eskasasnanda's students to experience working together, perhaps for the first time, and to get to know one another on a more personal level. Malang is a large city in East Java, and students at the university come from various cultural, social, and ethnic backgrounds. This can make it difficult for students from remote areas to blend into their new environment. However, the activities introduced into the classroom provided the students with the opportunity to learn about (and from) one another, to work collaboratively, to have fun in the process. In traditional lecture-based classes, only a few students (usually the brightest or most outspoken) tend to participate; the types of activities introduced by $\mathrm{Mr}$. Eskasasnanda encourage the participation of all. Since the purpose of these activities is to build an effective classroom culture, Mr. Eskasasnanda said his next challenge is how to integrate these non-academic activities into academic learning.

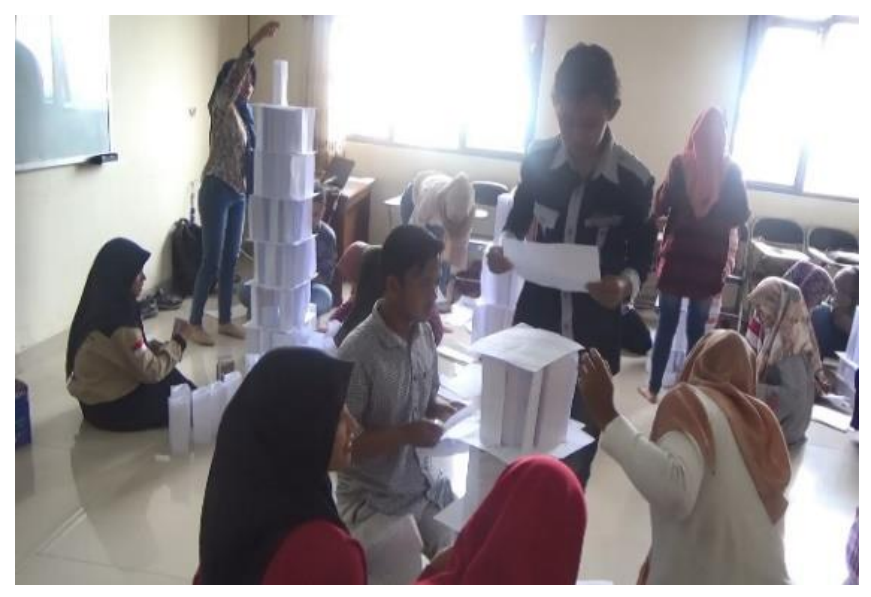

Fig. 2. Playing tokkatsu

\section{CONCLUSION}

Although the implementation of tokkatsu in Indonesia has been rather limited, several benefits and challenges seem apparent.

As the two examples above suggest, tokkatsu offers an opportunity for students to experience working together and respecting one another as members of a community. To date, the implementation of tokkatsu in Indonesia has been mainly at the classroom level and limited to building classroom culture. The reason for this is that the introduction of tokkatsu stems primarily from the initiative of individual, motivated teachers/lecturers rather than being the product of a concerted effort at the institutional level. Even where it has been introduced, tokkatsu tends to be treated as a specialized activity to develop social and noncognitive skills. However, at least at Scool Y, there is an ongoing effort to integrate various activities at the school level.

Since teachers implement tokkatsu as a way to nurture the noncognitive aspects of their students, they are able to "facilitate" learning rather than "teach." In academic group work, teachers have traditionally dominated the pace of discussion and controlled the content of the discussion in order to lead the students to finding the "correct" answer. In a tokkatsu activity, however, teachers are less concerned about controlling the activity and thus are better able to focus on their role as facilitator. By engaging students in non-academic activities, the rigid structure of the existing classroom is challenged. In subject learning, only the stronger students are able to participate in group discussions. In contrast, in the non- 


\section{REFERENCES}

academic activities of tokkatsu, students are able to experience a more egalitarian relationship in which they enjoy supporting one another.

Tokkatsu in Indonesia differs from Japanese tokkatsu. Firstly, the implementation of tokkatsu in Indonesia is currently dependent on the initiative, motivation and skills of individual teachers. This means that there will be challenges in integrating and standardizing various tokkatsu programs in Indonesian schools and universities. It is common that school/university leaders develop department plans and that teachers/lecturers merely implement what is assigned to them. In order to implement integrated tokkatsu, there needs to be a distribution of leadership. Secondly, although student activities provide students with the experience of learning-bydoing, these student activities are still managed by teachers rather than initiated by the students. To encourage students to be self-motivated and to take the initiative in their learning, more long-term and continuous effort is needed. Thirdly, learning in tokkatsu is still limited to acquiring values and social skills; it has not been integrated into academic learning or education for life. Future efforts to integrate the academic/nonacademic aspects of learning and collaboration relevant to education in life is needed.

There is an increasing demand for tokkatsu training and learning resources in Indonesia. A team from the University of Tokyo has been supporting motivated teachers and lecturers to facilitate the implementation of tokktsu. A tokkatsu website in three languages (English, Arabic, and Chinese) is also available to provide resources for those interested (http://www.p.u-tokyo.ac.jp/ tsunelab/tokkatsu/). This year, delegates from several Indonesian universities have visited the University of Tokyo to discuss a plan for implementing tokkatsu and conducting related research. In addition, a oneweek training program on tokkatsu was provided to a group of Indonesian teachers in Tokyo. As a modified version of tokkatsu, Tokkatsu Plus, has been implemented in Egypt. It is expected that a new variation of tokkatsu-one that fits the educational context of Indonesia - will soon be born.
[1] Nasution, R. (2018, November 27). "Making Indonesia 4.0" to face industrial revolution. $\quad$ Retrieved from https://en.antaranews.com/news/120818/making-indonesia-40-toface-industrial-revolution

[2] Kitamura, Y. (2017). Education for Sustainable Development (ESD) in Asia. In Oxford Research Encyclopedia of Education

[3] UNESCO (2007). The UN Decade of Education for Sustainable Development (DESD 2005-2014) The First Two Years. [ONLINE] Available

http://unesdoc.unesco.org/images/0015/001540/154093e.pdf (Accessed 27 November 2018).

[4] Tsuneyoshi, R. (2019). The Tokkatsu Framework: The Japanese Model of Holistic Education. In Tsuneyoshi, R. K., Sugita, H., Kusanagi, K., \& Takahashi, F. (Eds.), Tokkatsu: The Japanese Educational Model of Holistic Education (pp. 4-35). World Scientific.

[5] Tsuneyoshi, R. (ed.) (2012). The World of Tokkatsu. With the assistance of Tamaru, M. T. http://www.p.u.tokyo.ac.jp/ tsunelab/tokkatsu/

[6] Indriani, D. E. (2017). Character Education Based on Pancasila Values Through Curriculum 2013 on Primary Education Children in Madura. Jurnal Pendidikan Dasar Indonesia, 2 (1), 13-17.

[7] Stefanie, C. (2017, June 9). CNN Indonesia Jokowi Terbitkan Perpres Penguatan Pendidikan Karakter (Jokowi Issues Presidential Regulation on Strengthening Character Education). Retrieved from

[8] Cerdasberkarakter.kemdikbud.go.id. (2019). Kebijakan Penguatan Pendidikan Karakter - Penguatan Pendidikan Karakter. [online] Retrieved from https://cerdasberkarakter.kemdikbud.go.id/?page_id=132

[9] Wirawan, C. J. (2018, July 12). Pentingnya Program Penguatan Pendidikan Karakter untuk Siswa Sekolah Dasar. Liputan6. Retrieved from https://m.liputan6.com/citizen6/read/3585846/pentingnyaprogram-penguatan-pendidikan-karakter-untuk-siswa-sekolah-dasar

[10] Kusanagi, K. (2019). Recontextualization of Professional Development: Bureaucratization of Lesson Study in a Junior Secondary School in Java. (Doctoral dissertation, UCL Institute of Education).

[11] Kusanagi, K. N. (2014). The Bureaucratising of Lesson Study: A Javanese Case. Mathematics Teacher Education and Development, 16(1), 1-17.

[12] MEXT. (2018). Basic Education in Japan. Retrieved from http://www.mext.go.jp/en/policy/education/brochure/title01/detail01/ __icsFiles/afieldfile/2018/10/09/1409899-01.pdf

[13] Eskasasnanda, I. D. P. (2019). Implementation of tokkatsu to improve face to face interaction between students. Paper Presented at the1st International Conference on Social Studies and Environmental Issues 